\section{Palliative care: science and protection at the end of life}

\author{
Cuidados paliativos: ciência e proteção ao \\ fim da vida
}

\author{
Cuidados paliativos: ciencia y protección en el \\ final de la vida
}

\footnotetext{
1 Faculdade de Medicina, Universidade do Porto, Porto, Portugal.

2 Instituto de Psicologia, Universidade Federal do

Rio de Janeiro, Rio de Janeiro, Brasil.

Correspondence

C. Burlá

Rua Artur Araripe 43, apto

1003, Rio de Janeiro, RJ

22451-020, Brasil.

claudiaburla@gmail.com
}

In the context of contemporary medicine, submerged in a kind of technological imperative that dominates daily clinical practice, the modern hospice movement is emerging within palliative care. The movement is emerging in an ethos based on compassion and care for patients and their families, seen as a unit, in an active search for measures to relieve the anguishing symptoms - especially pain - and thus relieve suffering, while facing death as part of the natural process of life history rather than as an enemy in battle. Curiously, in the age of high biotechnology, a modality of care for persons that are dying proves to be an interdisciplinary intervention with a revolutionary thrust: a hasty look fails to capture the dimension of palliative care, a health field praxis that combines scientific knowledge, bioethical interpellation, and sensitivity in the face of human suffering 1,2,3,4.

Health professionals trained to take every possible measure to keep patients alive are bewildered when they find individuals with advancedstage chronic illnesses that no longer respond to any curative therapy. Here, technical knowledge and humanitarian skill are equally important in an exercise of humility to perceive the limits of life. At this moment, professional action does not aim to artificially prolong life, but to provide possible comfort for persons to live as fully as they can until the moment of death.
Claudia Burlá 1

Ligia Py 2

Importantly, palliative care does not reject biotechnology. On the contrary, it is a highly interventionist treatment modality, drawing on advanced proposals in pharmacology to effectively control symptoms, for example. It is an active response to the problems arising from a prolonged, incurable, and progressive illness. It harmoniously combines science with humanism. Health professionals must have the personal maturity to perceive the patient's demands, as well as to know the diseases involved in depth and the possibilities for pharmacological and non-pharmacological intervention.

The World Health Organization (WHO) has issued an alert: in developed and developing countries, persons are living and dying alone and full of fear, their pain unmitigated, their physical symptoms uncontrolled, and their psychosocial and spiritual issues unattended. Progression of the advanced-stage chronic illness makes death inevitable, and any curative therapy can be considered futile and unreasonable 5 .

Such is the challenging reality of palliative care, which still lacks public policies that include this innovative, highly pertinent, and effective form of care. The large contingent of persons with life-threatening illnesses demands care that extends its scope to the control of symptoms, psychosocial and spiritual care, and proper attention to families. 
Palliative care has its origins in the dawn of Medicine. Since Hippocrates, the physician must "cure sometimes, treat often, comfort always" 6.

The etymological root of the adjective palliative is the Latin "pallium" (cloak), which encompasses a wide semantic circle, highlighting here two intersecting and complementary meanings: 1) that which cloaks, protects, wraps, relieves, and defends and 2) distinction, uniqueness, individualization, and power. The latter is understood as duty and mission, not as domination or honor. With etymological considerations as the point of departure, palliative care is not limited to the one who is cared for, but extends to the one giving care. It thus constitutes a profoundly intersubjective process of close personal relationship. Such a relationship assumes a radical belief in the person's suffering and an intense attitude of availability 7 .

The concept of palliative care evolved over time, with relevance for patients, their special needs, and their families, no longer for the organ involved, age, or type of disease. Palliative care used to be viewed as applicable exclusively at the moment of impending death. Today, palliative care is offered in the initial stage of a progressive, advanced, and incurable illness.

Alert to the issue's timeliness, importance, and pertinence, the World Health Organization offers a detailed explanation with emphasis on crucial aspects in the specificity of its application. Palliative care relieves pain and other symptoms that cause suffering; it reaffirms life and sees death as a natural process; it does not intend to either anticipate or postpone death; it integrates psychosocial and spiritual aspects into care; it offers a support system that helps patients live as actively as possible until death and the families and other loved ones to feel assisted throughout all the process of the illness and grieving; it uses all the resources of a multidisciplinary team to focus on the needs of patients and their families, including follow-up in grieving; it improves quality of life and influences the disease course positively; it should be initiated as early as possible, together with other measures to prolong life - such as chemotherapy and radiotherapy and to include all the necessary tests to elucidate and manage the symptoms 5 .

Palliative care as an intervention modality differs from hospice care. Palliative care should be applied as a continuum, in step with other treatment pertaining to the case, based on the diagnosis of an incurable and progressive ill- ness. Hospice care is an important part of palliative care, referring to the treatment patients should receive in the final stage of their lives, when it becomes clear that they are in a state of progressive and inexorable decline, approaching death 8 .

Palliative care is spreading worldwide and has reached Brazil: "This dissemination appears to be irreversible and has become not only a technical necessity, pertaining to the health team's professional knowhow, but also a moral imperative, due to the situations of abandonment experienced by patients, who need interventions that are consistent with relieving their suffering at the end of life" 3 .

The palliative care proposal is essentially ethical, especially in the context of end of life. It moves within conventional treatment, transgresses the aegis of disease, and offers to transform care for persons with illnesses leading them ineluctably to the end of life.

Listening to patients, extending to them the palliation of protection and care, and touching them and being touched by them in the shadow of death can fill a gap in a learning process that lights the existential path of health professionals, encouraging them to embrace new projects, new dreams, and thus new achievements.

Palliative care is not a lesser form of care in the health system, is not limited to a charitable, well-meaning intervention, does not target a limited number of situations, and does not only apply to the dying in their final days of life. Based on the interventions' specificity, it differs from continuing care. Palliative care is not essentially costly and does not increase the health systems' expenditures: in fact, it tends to reduce them due to greater rationalization of care 9

The population aging issue is illustrative. With the obvious increase in average longevity, cancer and cardiovascular diseases have become the leading causes of high morbidity and mortality rates among the elderly; neurodegenerative and musculoskeletal diseases are at the base of the disability that affects the elderly population, jeopardizing their autonomy with major functional impairment and a high degree of dependence in activities of daily living.

Palliative care has become a public health issue. It is an indispensable response for persons with chronic problems evolving towards the end of life. In the name of ethics, dignity, and each human's wellbeing, it is increasingly necessary to make palliative care a reality. 
1. Campbell CS, Hare J, Matthews P. Conflicts of conscience: hospice and assisted suicide. Hastings Cent Rep 1995; 25:36-43.

2. Dunlop R. Cancer: Palliative Care. London: Springer-Verlag; 1998.

3. Floriani CA. Moderno movimento hospice: fundamentos, crenças e contradições na busca da morte. Rio de Janeiro: Publit; 2011.

4. Twycross R. Introducing Palliative Care. UK: Radcliffe Medical Press; 1995.

5. World Health Organization. Cancer: palliative care is an essential part of cancer control. http:// www.who.int/cancer/palliative/en (accessed 13/ May/2014).

6. Doyle D, Hanks G, Cherny NI, Calman K. Introduction. In: EDITOR. Oxford Textbook of Palliative Medicine. $3^{\text {rd }}$ Ed. New York: Oxford University Press; 2004. p. 1-4.
7. Oliveira JF. O amplo significado de 'pálio': a matéria prima do que se entende por 'cuidados paliativos'. Py L et al. "Cuidados paliativos e cuidados ao fim da vida na velhice". Geriatria \& Gerontologia. 2010; 4(2): 90-106.

8. Watson M, Lucas C, Hoy A, Wells J. Oxford Handbook of Palliative Care. 2nd Ed. New York: Oxford University Press; 2009.

9. Temel JS, Greer JA, Muzikansky A, Gallagher ER, Admane S, Jackson VA, et al. Early palliative care for patients with metastatic non-small-cell lung cancer. N Engl J Med 2010; 363:733-42.

Submitted on 20/May/2014

Approved on 26/May/2014 